\title{
Nutritional rickets at puberty
}

\author{
M. W. MONCRIEFF, H. R. W. LUNT, and L. J. H. ARTHUR \\ From the Derbyshire Children's Hospital, Derby
}

\begin{abstract}
Moncrieff, M. W., Lunt, H. R. W., and Arthur, L. J. H. (1973). Archives of Disease in Childhood, 48, 221. Nutritional rickets at puberty. Four adolescent Asians with vitamin D deficiency rickets were seen in Derby in the 5 years 1967 to 1971. They had an extremely low intake of vitamin D, and this, combined with the extra metabolic demands of puberty, was judged to be the main cause of the rickets. However, since investigation of their sibs revealed 4 further cases of rickets, it is possible that some of these children had an inherited disability in the metabolism of vitamin D. 2 cases of iron deficiency anaemia were found among their sibs. We suspect that nutritional deficiencies may be widespread in the Asian community in Britain and that prevention depends on dietary education.
\end{abstract}

Rickets due to dietary deficiency of vitamin $\mathrm{D}$ usually occurs in the first two years of life and is particularly common in infants from large families with poor social circumstances (Arneil and Crosbie, 1963). Nutritional rickets may also occur during rapid growth at puberty, but is considerably rarer at this age. Indeed, Albright et al. (1946) in a long review of osteomalacia and late rickets, stated that they were 'cognizant of no single case in the United States due to simple vitamin D lack'. Nutritional osteomalacia and late rickets in Indian and Pakistani immigrants, including a number of children under 15 years of age, have been reported from Glasgow (Dunnigan et al., 1962; Ford et al., 1972) and from Birmingham (Swan and Cook, 1971).

In the 5 years, 1967 to 1971 , we have seen 18 cases of nutritional rickets in Derby, 16 of the patients were coloured. This hospital serves an urban population of approximately 220,000 , of whom 10,000 are coloured immigrants. The age at diagnosis of the 18 cases is shown in the Fig. superimposed on a height velocity chart, to emphasize the relation between rickets and rapid growth. $4(22 \%)$ of our cases were young adolescents. In this paper we describe these 4 cases in detail, and report the results of dietary and family studies.

\section{Patients}

The 4 patients were from India or Pakistan; 3 were girls. One presented with vague limb pain, another with march fractures of three metatarsals, the third with knock-knees and limb pain, and the fourth was completely

Received 14 July 1972. asymptomatic, rickets being found on a wrist $x$-ray when she attended the local casualty department after falling on her arm. All had previously been well, and were attending local schools. The 3 girls had started menstruating a few months earlier, and the boy showed features of early puberty. 3 were above the expected height for their weight (by English standards). The child with knock-knees had swelling of the wrists and costochondral junctions, but the other 3 had no physical stigmata of rickets. Some clinical details of these children are given in Table I.

Active rickets was present radiologically in each case and all had raised serum alkaline phosphatase, and low calcium levels; 3 had a low level of serum phosphate. The blood urea level was normal in each case as was the

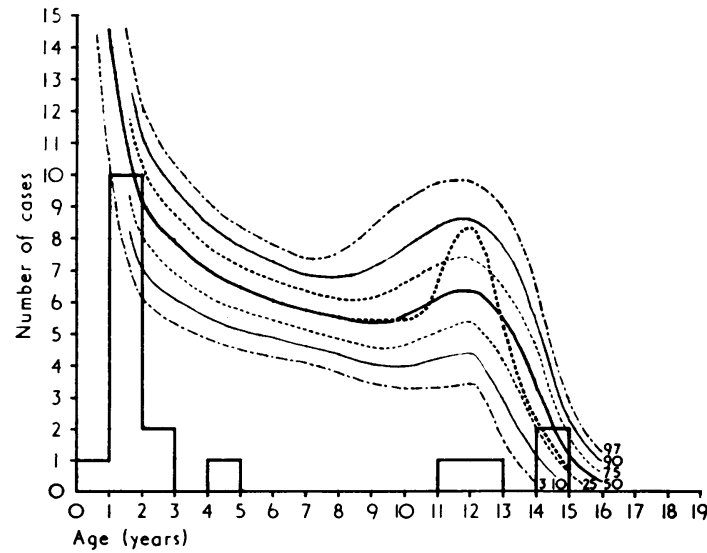

FIG.-Number of cases of nutritional rickets seen in Derby 1967 to 1971, superimposed on a growth velocity chart. 
TABLE I

Some clinical features of 4 Asian adolescents with rickets

\begin{tabular}{|c|c|c|c|c|c|c|c|}
\hline Case no. & $\begin{array}{l}\text { Age at diagnosis } \\
(y \mathbf{y})\end{array}$ & Sex & $\begin{array}{l}\text { Height } \\
\text { (cm) }\end{array}$ & (centile) & $\begin{array}{l}\text { Weight } \\
\text { (kg) }\end{array}$ & (centile) & Clinical features \\
\hline $\begin{array}{l}1 \\
2 \\
3 \\
4\end{array}$ & $\begin{array}{l}11 \cdot 9 \\
14 \cdot 3 \\
12 \cdot 8 \\
14 \cdot 5\end{array}$ & $\begin{array}{l}\text { M } \\
\text { F } \\
\text { F }\end{array}$ & $\begin{array}{l}150 \\
160 \\
144 \\
149\end{array}$ & $\begin{array}{r}\text { (75th) } \\
(50 \text { th) } \\
(3 \mathrm{rd}) \\
(3 \mathrm{rd})\end{array}$ & $\begin{array}{l}36 \\
38 \\
39 \\
35\end{array}$ & $\begin{array}{r}(50 \mathrm{th}) \\
(3 \mathrm{rd}) \\
(25 \mathrm{th}) \\
(<3 \mathrm{rd})\end{array}$ & $\begin{array}{l}\text { Pain in limbs } \\
\text { March fracture } 3 \text { metatarsals } \\
\text { Pain in limbs; knock-knees; sw ollen } \\
\text { wrists; rickety rosary } \\
\text { None }\end{array}$ \\
\hline
\end{tabular}

TABLE II

Biochemical findings in 4 Asian adolescents with rickets

\begin{tabular}{|c|c|c|c|c|c|c|c|c|}
\hline \multirow[b]{2}{*}{ Case no. } & \multicolumn{4}{|c|}{ Blood } & & \multirow{2}{*}{ 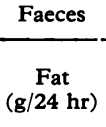 } & \multicolumn{2}{|c|}{ Urine } \\
\hline & $\underset{(\mathrm{mg} / 100 \mathrm{ml})}{\mathrm{Ca}}$ & $\frac{\mathrm{PO}_{4}}{(\mathrm{mg} / 100 \mathrm{ml})}$ & $\begin{array}{c}\text { Alkaline } \\
\text { phosphatase } \\
\text { (KA units) }\end{array}$ & $\begin{array}{c}\text { Urea } \\
(\mathrm{mg} / 100 \mathrm{ml})\end{array}$ & $\begin{array}{l}\text { Bicarbonate } \\
(\mathrm{mEq} / 1 .)\end{array}$ & & Amino acids & $\begin{array}{c}\mathrm{Ca} \\
(\mathrm{mg} / 24 \mathrm{hr})\end{array}$ \\
\hline $\begin{array}{l}1 \\
2 \\
3 \\
4\end{array}$ & $\begin{array}{l}8 \cdot 8 \\
7 \cdot 6 \\
8 \cdot 4 \\
9 \cdot 3\end{array}$ & $\begin{array}{l}5 \cdot 2 \\
2 \cdot 8 \\
3 \cdot 0 \\
2 \cdot 0\end{array}$ & $\begin{array}{r}82 \\
84 \\
44 \\
111\end{array}$ & $\begin{array}{l}19 \\
16 \\
11 \\
28\end{array}$ & $\begin{array}{l}27 \\
31 \\
24 \\
-\end{array}$ & $\begin{array}{c}1 \cdot 5 \\
0 \cdot 3 \\
1 \cdot 0 \\
-\end{array}$ & $\begin{array}{c}\text { Normal } \\
\text { Normal } \\
\text { Normal } \\
-\end{array}$ & $\begin{array}{l}28 \\
32 \\
66 \\
-\end{array}$ \\
\hline
\end{tabular}

serum bicarbonate in the 3 in whom it was measured. Faecal fat was not increased in 3 children, but was not measured in the fourth. None had reducing substances or protein in the urine. Urinary amino acid excretion was normal and calcium excretion reduced in the 3 children in whom they were measured. Detailed results of the biochemical investigations are given in Table II.

The children were treated with small doses of calciferol 1000 to 3000 units daily, and the rickets healed radiologically in a few months in each case. The abnormal biochemical findings also returned to normal in 3 children and were improving in the fourth, who was lost to follow-up as he suddenly returned to India.

Diet. A dietary history was taken by the recall method by the hospital dietitian from the 3 girls, and by the medical staff from the boy. The approximate calcium, vitamin $\mathrm{D}$, protein, phytic acid, and calorie contents of the diets have been calculated using the figures given by McCance and Widdowson (1960), and the results are shown in Table III. This shows that all the children had an extremely low intake of vitamin $D$, and a very high intake of phytic acid; 3 had a poor intake of calcium. Only 1 took a satisfactory amount of protein and $2 \mathrm{had}$ an adequate intake of calories.

Their food consisted mainly of chapattis and curried vegetables, together with a little butter or cheese. 2 children ate a little meat and fish. 2 of the girls disliked, and refused to eat, meat, eggs, or fish; the third girl ate an egg a day except during her menstrual period; and the boy ate about three eggs a week. He drank a pint of milk daily, 2 of the girls half a pint, and the third girl only about three ounces. The 3 girls came home from school for lunch, but we do not know if the boy did. The children were well cared for and the families, though large, were not impoverished. The deficient diet appears to be partly due to the children's personal wishes, but social and ethnic factors are probably also involved.

Family study. The 4 children had 19 sibs, but only 16 were seen as the other 3 were in India. Each sib had a wrist $x$-ray, and measurement of serum calcium, phosphorus, and alkaline phosphatase levels, and $\mathrm{Hb}$ concentration. 4 had a raised alkaline phosphatase level, only 1 of whom had rickets radiologically, and 2 had an iron deficiency anaemia. Details of these

\section{TABLE III}

Details of diet in 4 adolescent Asians with rickets: estimated quantities per day

\begin{tabular}{c|c|c|c|c|c}
\hline $\begin{array}{c}\text { Case } \\
\text { no. }\end{array}$ & $\begin{array}{c}\text { Vitamin } \\
\text { D } \\
\text { (units) }\end{array}$ & $\begin{array}{c}\text { Ca } \\
\text { (mg) }\end{array}$ & $\begin{array}{c}\text { Phytic acid } \\
\text { phosphorus } \\
\text { (mg) }\end{array}$ & $\begin{array}{c}\text { Protein } \\
\text { (g/kg) }\end{array}$ & $\begin{array}{c}\text { Calories } \\
\text { (kg) }\end{array}$ \\
\hline 1 & 45 & 910 & 270 & $1 \cdot 8$ & 55 \\
2 & 30 & 740 & 283 & $1 \cdot 2$ & 65 \\
3 & 20 & 350 & 269 & $1 \cdot 0$ & 47 \\
4 & 20 & 550 & 265 & $0 \cdot 9$ & 71 \\
Normals & $400^{\star}$ & $970^{\star}$ & $78 t$ & $2 \cdot 0^{\star}$ & $70^{\star}$ \\
\hline
\end{tabular}

*Laupus and Bennett (1969).

†Dunnigan and Smith (1965). 
cases are shown in Table IV. The children were treated with calciferol or iron as appropriate. The rickets has healed, and the anaemic children now have a normal $\mathrm{Hb}$ concentration. Dietary advice has been given to the families.

TABLE IV

Findings in 6 sibs of 4 children with rickets

\begin{tabular}{|c|c|c|c|c|}
\hline \multirow{2}{*}{ Case no. } & \multicolumn{4}{|c|}{ Sibs } \\
\hline & $\begin{array}{l}\text { Age } \\
(\mathrm{yr})\end{array}$ & Sex & $\begin{array}{l}\text { Alkaline phosphatase } \\
\text { over } 25 \mathrm{KA} \text { units }\end{array}$ & $\begin{array}{c}\mathrm{Hb} \\
(<10 \mathrm{~g} / 100 \mathrm{ml})\end{array}$ \\
\hline $\begin{array}{l}1 \\
2 \\
\text { ", } \\
3 \\
\text { ", }\end{array}$ & $\begin{array}{r}1 \frac{1}{2} \\
3 \\
2 \\
12 \\
4 \\
8\end{array}$ & $\begin{array}{l}\mathbf{F} \\
\mathrm{F} \\
\mathbf{M} \\
\mathrm{F} \\
\mathrm{F} \\
\mathrm{F}\end{array}$ & $\begin{array}{l}+{ }^{*} \\
0 \\
0 \\
+ \\
+ \\
+\end{array}$ & $\begin{array}{l}0 \\
+ \\
+ \\
0 \\
0 \\
0\end{array}$ \\
\hline
\end{tabular}

$\star_{\text {radiological rickets present. }}$

+ present; 0 absent.

\section{Discussion}

Clinically, one child presented with knock-knees and, together with another child, complained of vague limb pains which could easily be considered psychogenic. We consider that all adolescent Asians with this complaint should be investigated for the presence of rickets. These patients are similar to those reported by Dunnigan et al. (1962), Ford et al. (1972), and Swan and Cook (1971), who all noted vague limb pains as the commonest complaint.

There was no evidence of renal disease or malabsorption in these children, and they appeared to be suffering from simple 'nutritional rickets'. Confirmation of the diagnosis was provided by the rapid response to small doses of vitamin $D$.

There are several possible causes for rickets in Asian adolescents. Low vitamin D intake, together with lack of sunlight and skin pigmentation, was originally thought by Dunnigan et al. (1962) to be the main cause. However, Ford et al. (1972), in discussing further cases from Glasgow, revised this opinion. They noted that their patients, being Punjabis, were not deeply pigmented, and that white adolescents subjected to the same degree of lack of sunlight did not develop rickets. Because of the familial occurrence of rickets they suggested a possible endogenous factor, perhaps due to a genetic disability to synthesize cholecalciferol or to convert it to its more active metabolites.

Dietary deficiency of vitamin $\mathrm{D}$ appeared to be the main cause of osteomalacia in Indian adults, studied by Dent and Smith (1969). Osteomalacia in adults and rickets in adolescents were thought to be of similar aetiology by Swan and Cook (1971), but they felt that not all their cases were due to low dietary vitamin $D$, as some required as much as $2.5 \mathrm{mg}$ vitamin $\mathrm{D}$ daily before healing occurred. They therefore suggested that in some cases there was a defect in the metabolism of calciferol.

High dietary phytic acid was considered to be an important aetiological factor by Wills et al. (1972), in a further case, as healing occurred after reduction of the phytic acid content of the diet without increase in vitamin $\mathrm{D}$ content.

In our cases we consider the main cause of rickets to be the extremely low intake of vitamin $D$, combined with increased metabolic demands due to rapid growth at puberty, a point not previously stressed. However, on the basis of the family studies, we agree with Ford et al. (1972) that an inherited disability of the metabolism of vitamin $\mathrm{D}$ may be present in some of these children. In the family of Case 1 , for example, 2 children had obvious rickets, while the remaining 4 were normal. It is likely that all 6 children had similar food intakes and exposure to sunlight; a possible explanation is that the 2 affected children developed rickets because their metabolism required a larger intake of vitamin D.

Though rickets will probably heal spontaneously in the majority of Asian adolescents when rapid growth at puberty is over, the condition is not completely benign as shown by Case 3 who required surgical correction of her deformities. It is also worth while trying to correct dietary deficiencies in these children in order to avoid nutritional osteomalacia which is likely to occur during pregnancy (Swan and Cook, 1971).

Extending our study to the families revealed a high incidence of rickets in sibs and is in keeping with the findings of Dunnigan et al. (1962) and Ford et al. (1972). This suggests that mild rickets in adolescents is widespread in the Asian community. Most of the younger sibs, born in this country, were fed on vitamin D-fortified powdered milk, and so avoided rickets in infancy. The finding of anaemia in 2 sibs suggests that nutritional deficiency in general is common in immigrant children.

We feel that prevention of rickets, and other nutritional diseases in Asian immigrants, will ultimately depend on persuading them to change their eating habits, and in Derby a programme of dietary education for the immigrants has been started by the Medical Officer of Health.

We thank Dr. V. M. Leveaux for letting us include Case 4, and Mrs. J. Hulme, the Children's Hospital dietitian, for supplying us with details of the children's diets. 
REFEKENCES

Albright, F., Burnett, C. H., Parson, W., Reifenstein, E. C., and Roos, A. (1946). Osteomalacia and late rickets. Medicine, $25,399$.

Arneil, G. C., and Crosbie, J. C. (1963). Infantile rickets returns to Glasgow. Lancet, 2, 423.

Dent, C. E., and Smith, R. (1969). Nutritional osteomalacia. Quarterly Fournal of Medicine, 38, 195.

Dunnigan, M. G., Paton, J. P. J., Haase, S., McNicol, G. W. Gardner, M. D., and Smith, C. M. (1962). Late rickets and osteomalacia in the Pakistani community in Glasgow. Scottish Medical fournal, 7, 159.

Dunnigan, M. G., and Smith, C. M. (1965). The aetiology of late rickets in Pakistani children in Glasgow. Report of a diet survey. Scottish Medical fournal, 10, 1.

Ford, J. A., Colhoun, E. M., McIntosh, W. B., and Dunnigan, M. G.
(1972). Rickets and osteomalacia in the Glasgow Pakistani community, 1961-71. British Medical fournal, 2, 677.

Laupus, W. E., and Bennett, M. J. (1969). Nutritional requirements. Textbook of Pediatrics, 9th ed., p. 127. Ed. by W. E. Nelson, V. C. Vaughan, and R. J. McKay. Saunders, Philadelphia.

McCance, R. A., and Widdowson, E. M. (1960). Composition of Foods. H.M.S.O., London.

Swan, C. H. J., and Cook, W. T. (1971). Nutritional osteomalacia in immigrants in an urban community. Lancet, 2, 456.

Wills, M. R., Day, R. C., Phillips, J. B., and Bateman, E. C. (1972) Phytic acid and nutritional rickets in immigrants. Lancet, 1 , 771.

Correspondence to Dr. M. W. Moncrieff, Derbyshire Children's Hospital, North Street, Derby DE1 3BA 